\title{
PENINGKATAN PENGETAHUAN HAK KEKAYAAN INTELEKTUAL GURU- GURU MAN 3 JAKARTA DALAM MENUMBUHKAN KESADARAN BERKEKAYAAN INTELEKTUAL
}

\author{
Endang Purwaningsih, Chandra Yusuf, Mohammad Ryan Bakry \\ Sekolah Pascasarjana, Universitas YARSI \\ Email : e.purwaningsih@yarsi.ac.id
}

\begin{abstract}
In Article 14 of Law Number 14 of 2005 concerning Teachers and Lecturers, it is stated among other things the right of the teacher to obtain protection in carrying out duties and intellectual property rights; get the opportunity to improve competence; and obtain and utilize learning facilities and infrastructure to support the smooth functioning of professionalism; so it is appropriate if the teacher has intellectual property rights. Activities to increase teacher knowledge related to intellectual property rights have been well implemented, relevant to the interests of State Madrasah Aliyah 3 (MAN 3), and carried out by lecture and training methods with a participatory approach. There is a significant increase in MAN 3 teacher knowledge about the scope of IPR (20-60\%). Likewise, IPR legal counseling can increase the knowledge of IPR teachers to be more aware of intellectual property by being done programmatically, synergies between community services Team, Structural MAN 3 and participants (teachers). Factors supporting the growth of teacher legal awareness of IPR include the development of the digital age of technology that must be well adapted by teachers in their profession and the need to protect teacher creativity and innovation. An obstacle to the growing legal awareness of teachers towards IPR is only to change the mindset that makes the module or work just meet the teacher's credit and the obligation of teaching materials for each teacher.
\end{abstract}

Keywords: IPR, teacher, Madrasah Aliyah, Jakarta

\section{PENDAHULUAN}

Peningkatan kesadaran hukum dapat dilakukan dengan penyuluhan hukum secara terus menerus sampai subyek/peserta merasa paham dan menyadari serta taat hukum. Rendahnya kesadaran hukum dapat disebabkan oleh kurangnya sosialisasi regulasi, edukasi, juga terbatasnya akses informasi. Struktural sekolah dan guru baik menyandang tugasnya sebagai fasilitator antara ilmu dan pembelajar, sekaligus juga memiliki tanggungjawab akan nasibnya sendiri dalam dunia keilmuan, yakni berhak mendapatkan penghargaan atas karya inovatif yang bersumber dari karya intelektualitanya.
Diperlukan pelatihan dilakukan tidak hanya sekedar memberi informasi, akan tetapi juga melatih, memberdayakan, agar para guru memahami apa dan bagaimana hak kekayaan intelektual, akan makin terbuka pengetahuannya. Bagi sekolah termasuk MAN 3, siswa dan guru adalah ladang potensial lahirnya invensi baru, yang mungkin saja layak untuk dihargai kekayaan intelektualnya.

Lemahnya kesadaran hukum di Indonesia antara lain disebabkan oleh: (1) kurangnya kepastian hukum, (2) adanya perlakuan yang berbeda terhadap warga masyarakat dan (3) masih lemahnya komitmen dari pihak 
penguasa dalam pelaksanaan hukum di masyarakat. $^{1}$

Dalam proses pembelajaran tentu guru lah yang memegang peran utama, untuk itu guru harus mengetahui terlebih dahulu dan memahami lebih banyak daripada siswanya. Guru perlu diperhatikan, baik dalam kompetensi maupun kinerjanya. Membangun kesadaran hukum adalah bagian dari membangun kehidupan moral bangsa secara keseluruhan yang tidak bisa menunggu sampai kesejahteraan hidup meningkat secara substansial. Pada waktu itu kemungkinan besar kita sudah terlambat. $^{2}$

Mencermati kondisi kesadaran hukum masyarakat awam masih cukup rendah dan pengetahuan hukum guru sebagai peserta juga masih kurang, artinya bahwa belum pernah sekalipun mereka diberi penyuluhan hukum, tentu penting dilakukan penyuluhan Hak Kekayaan Intelektual, guna lebih mensosialisasikan dan meningkatkan pengetahuan dan kesadaran hukum guru yang nantinya memberi daya dukung bagi pengayaan materi yang akan ditransfer ilmu -kan kepada para siswa. Selain pengayaan ilmu HKI kepada guru yang bisa ditularkan ke para siswa, pengusul ingin merangsang dan memacu guru untuk tidak hanya 'diam'sebagai guru yang notabene tersertifikasi, namun lebih inovatif dengan membenahi diri, menambah pengetahuan, dan menggali karya dari ide intelektualitanya, yang mungkin saja bernilai komersil dan dapat diajukan pelindungan kekayaan intelektual. Untuk itulah dengan berbekal sedikit ilmu HKI, pengusul termotivasi untuk berbagi ide demi peningkatan pengetahuan guru MAN3 terhadap HKI

1 BPHN, Seminar Hukum Nasional Keenam Buku I II, sebagaimana dikutip dalam Laporan Pengabdian Kepada Masyarakat Pengusul 2015. ${ }^{2}$ Ibid, hal 83 dalam menumbuhkan kesadaran berkekayaan intelektual.

Dari analisis situasi di atas, kondisi yang ada saat sebelum kegiatan adalah:

1. Pada umumnya (hampir 100\%) para guru MAN 3 Jakarta belum memahami secara benar tentang Hak Kekayaan Intelektual.

2. Para guru MAN 3 Jakarta belum pernah mendapatkan penyuluhan Hak Kekayaan Intelektual.

3. Para guru, khususnya guru MAN 3 Jakarta kesulitan memperoleh informasi Hak Kekayaan Intelektual.

Berdasarkan uraian di atas maka dapat disimpulkan bahwa rumusan masalahnya

1. Bagaimana penyuluhan hukum dapat meningkatkan pengetahuan HKI para guru agar makin sadar berkekayaan intelektual ?

2. Apakah faktor pendukung dan penghambat tumbuhnya kesadaran hukum guru terhadap HKI?

Tujuan kegiatan ini adalah:

1. Agar para guru memperoleh wawasan dan pengetahuan tentang HKI supaya makin sadar berkekayaan intelektual

2. Agar para guru memahami faktor pendukung dan penghambat tumbuhnya kesadaran hukum guru terhadap HKI dan menemukan solusinya

Hasil kegiatan ini dapat memberikan manfaat berupa:

1. Meningkatnya pengetahuan dan kesadaran hukum para guru MAN 3 Jakarta khususnya dalam memberi daya dukung pada proses pembelajaran peserta anak didiknya dan karya pribadi sebagai guru yang selayaknya memberi teladan

2. Meningkatnya kesadaran hukum guru MAN 3 Jakarta akan 
pentingnya berkekayaan intelektual dan melindunginya.

\section{KHALAYAK SASARAN}

Khalayak sasaran dalam program ini adalah Guru MAN 3 Jakarta sebanyak 35 orang.

\section{METODE KEGIATAN}

Pada awalnya Tim mengadakan wawancara awal dengan struktural tentang kebutuhan HKI mana yang diinginkan dippelajari lebih mendalam, diketahui bahwa para guru memerlukan tambahan pengetahuan lebih mendalam pada penguasaan hak cipta.

Kegiatan ini telah dilaksanakan dengan menggunakan metode participatory action didukung metode berikut:

1. Metode ceramah dan diskusi

Metode ini digunakan untuk menyampaikan materi penyuluhan yang bersifat kognitif seperti wawasan dan pengetahuan tentang HKI agar makin sadar berkekayaan intelektual

Pelaksanaan metode ini digunakan waktu sebanyak $40 \%$ untuk ceramah atau penyampaian materi, sedangkan sisanya $60 \%$ digunakan untuk diskusi dan tanya jawab.

2. Metode Pelatihan

Dalam metode ini, kegiatan utama yang dilaksanakan adalah pembimbingan dan pelatihan wawasan dan pengetahuan tentang HKI agar makin sadar berkekayaan intelektual. Kegiatan ini antara lain berupa pelatihan pembuatan artikel yang dapat dilindungi dengan hak cipta, memahami faktor pendukung dan penghambat tumbuhnya kesadaran hukum guru terhadap HKI khususnya hak cipta dan HKI umumnya dan menemukan solusinya.

\section{HASIL DAN PEMBAHASAN}

Kegiatan telah dilaksanakan dengan baik, dan terjadi peningkatan pengetahuan guru MAN3 yang signifikan tentang HKI (20-60\%). Demikian juga diketahui bahwa penyuluhan hukum HKI dapat meningkatkan pengetahuan HKI para guru agar makin sadar berkekayaan intelektual dengan dilakukan secara terprogram, sinergi antara Tim abdimas, Struktural MAN3 dan peserta (guru). Berdasarkan Pasal 1 UndangUndang nomor 14 tahun 2005 tentang Guru dan Dosen, Guru adalah pendidik profesional dengan tugas utama mendidik, mengajar, membimbing, mengarahkan, melatih, menilai, dan mengevaluasi peserta didik pada pendidikan anak usia dini jalur pendidikan formal, pendidikan dasar, dan pendidikan menengah. Pada Pasal 14 UU tersebut disebutkan antara lain hak guru: (1) memperoleh perlindungan dalam melaksanakan tugas dan hak atas kekayaan intelektual; (2) memperoleh kesempatan untuk meningkatkan kompetensi; (3) memperoleh dan memanfaatkan sarana dan prasarana pembelajaran untuk menunjang kelancaran tugas keprofesionalan; (4) memiliki kebebasan dalam memberikan penilaian dan ikut menentukan kelulusan, penghargaan, dan/atau sanksi kepada peserta didik sesuai dengan kaidah pendidikan, kode etik guru, dan peraturan perundang-undangan; dan lain-lain.

Guru adalah unsur penting yang menentukan berhasil tidaknya pendidikan. Jika guru berkualitas baik, maka pendidikanpun akan baik. Jikalau tindakan para guru dari hari ke hari bertambah baik, maka akan menjadi lebih baik pulalah keadaan dunia pendidikan kita. Sebaliknya, kalau tindakan dari hari ke hari makin memburuk, maka makin parahlah dunia pendidikan kita. Guru-guru kita dapat disamakan dengan pasukan tempur yang 
menentukan kemenangan atau kekalahan dalam perang ${ }^{3}$.

Selama ini guru menjadi inspirasi dan teladan bagi peserta didiknya, seperti peribahasa: Guru kencing berdiri, murid kencing berlari: yang bermakna para peserta didik akan meniri perilaku gurunya, maka guru seharusnya lah memberi teladan yang baik, inovatif dan positif. Jika terdapat siswa yang pintar membuat robot, menjadi juara olimpiade, maka di balik layar tentu terdapat guru-guru yang potensi akademiknya luar biasa, memberi daya dukung ipteks dan motivasi kepada peserta didiknya untuk makin maju. Selayaknya lah guru dihargai dan diberi kesempatan untuk menunjukkan karya intelektualitanya dalam bentuk kekayaan intelektual.

Jika mencermati muatan hak kekayaan intelektual, tercantum dalam Trade Related Aspects of Intellectual Property Rights (TRIPs) yang menyebutkan Intellectual Property Rights meliputi:

1. Hak Cipta (Copyrights) dan hak terkait lainnya yakni hak-hak pelaku (rights of performers), produser rekaman suara dan lembaga penyiaran (producers of soundrecording and broadcasting organizations)

2. Merek (Trademarks)

3. Indikasi Geografis (Geographical Indications)

4. Desain Industri (Industrial Design)

5. Paten (Patent)

6. Desain Rangkaian Sirkuit Terpadu (Layout Design of Integrated Circuits)

http://menzour.blogspot.com/2016/03/makalahmenganalis-uu-guru-dan-dosen.html diakses 13 Agustus 2018
7. Informasi Rahasia, Rahasia Dagang dan Data Test (Undisclosed Information, Trade Secret and Test Data)

8. Varietas Tanaman Baru (New Plant Varieties)

Guru tidak ubahnya dosen, di satu sisi harus senantiasa mengembangkan kompetensi diri dalam segala hal terkait keilmuannya, di sisi lain juga harus dilindungi hasil cipta rasa karsanya dalam wujud karya intelektual, yang menjadi aset potensial bagi diri, sekolah dan masa depan pendidikan. Guru bisa sangat potensial melahirkan hak kekayaan intelektual seperti hak cipta dan hak paten. Perlu akses informasi yang memadai untuk peningkatan kemampuan dan kreatifitas guru. Guru dihadapkan pada upaya membangun diri dan membangun masa depan peserta didiknya, juga masyarakat banyak.

Dalam upaya menyeimbangkan hak-hak pemilik hak cipta dengan kepentingan masyarakat luas untuk memperoleh akses informasi, Undangundang mengenai hak cipta diberbagai negara mengizinkan penggunaan ciptaan-ciptaan tertentu tanpa perlu izin pencipta konsep ini biasa disebut penggunaan wajar/fair-dealing ${ }^{4}$.

Banyak pihak maupun guru yang belum memahami bahwa hak cipta diperoleh tanpa harus mendaftarkan, karena hak cipta bersifat automatic protection. Para penegak hukum seharusnya juga memahami, jangan berpatokan hanya pada 'yang terdaftar". Biasanya dengan dalih untuk menjamin keamanan ciptaannya, seorang pencipta dalam mengeksploitasi (tujuan komersial) akan memilih untuk mendaftarkan ciptaan ke Direktorat Jenderal Kekayaan Intelektual

\footnotetext{
${ }^{4}$ Tim Lindsley, dkk, 2011. Hak Kekayaan Intelektual suatu Pengantar, Bandung: PT Alumni hal.123
} 
Departemen Hukum dan HAM. Pendaftran yang selama ini dikenal, kemudian dalam UU baru (UU nomor 28 tahun 2014) menjadi pencatatan. Beberapa UU baru seperti UU nomor 13 tahun 2016 tentang Paten dan UU nomor 20 tahun 2016 tentang Merek tentu belum dipahami oleh para guru. Konsep economic right dan moral right harus selalu diingat oleh para akademisi.

Faktor pendukung tumbuhnya kesadaran hukum guru terhadap HKI antara lain perkembangan era digital teknologi yang harus diadaptasi dengan baik oleh para guru dalam profesinya dan kebutuhan perlindungan kreativitas serta inovasi guru. Penghambat tumbuhnya kesadaran hukum guru terhadap HKI hanyalah merubah mindset yang membuat modul atau karya sekedar memenuhi kredit kum guru dan kewajiban bahan ajar mata pelajaran masing-masing guru. ini dan berharap para guru MAN3 termotivasi untuk terus membuat karya ilmiah dan HKI lain yang dimungkinan dan melindungi karya-karya tersebut dengan hak kekayaan intelektual. Berikut rincian hasil kuesioner terhadap peserta berjumlah 35 guru.

\section{Pemahaman tentang Hak Kekayaan Intelektual (HKI)}

Sebelum pelatihan, jumlah guru yang belum memahami tentang Hak Kekayaan Intelektual (HKI) dalam arti hanya mendapatkan skor di bawah sebanyak 17 orang, akan tetapi setelah pelatihan, jumlah guru yang mendapatkan skor tiga ke bawah hanya 6 orang. Sehingga ada kenaikan kemampuan guru dalam memahami hak kekayaan intelektual, sebanyak 11 orang $(25 \%)$.

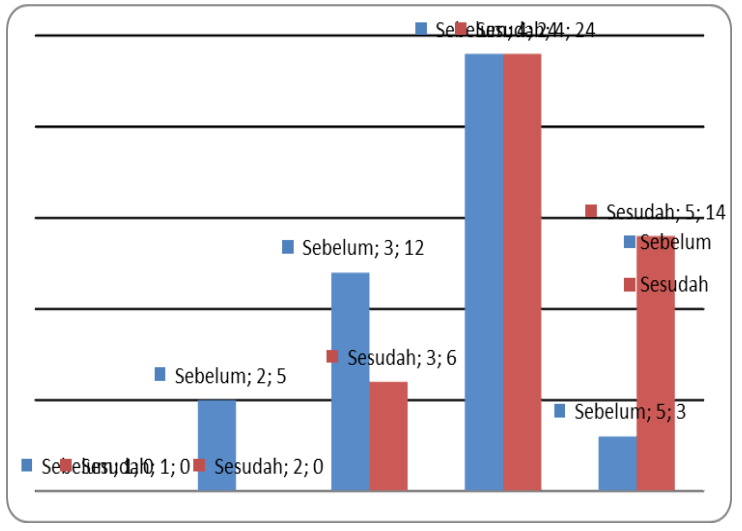

Diagram 1. Pemahaman tentang

Hak Kekayaan Intelektual (HKI)

\section{Pemahaman perbedaan hak cipta (copyrights) dengan hak paten (yang tergabung dalam industrial property rights)}

Sebelum pelatihan, jumlah guru yang belum memahami perbedaan hak cipta (copyrights) dengan hak paten (yang tergabung dalam industrial property rights) dalam arti hanya mendapatkan skor di bawah atau sama dengan 3 sebanyak 25 orang, akan tetapi setelah pelatihan, jumlah guru yang mendapatkan skor di bawah atau sama dengan 3 hanya 7 orang. Sehingga ada kenaikan kemampuan guru dalam memahami perbedaan hak cipta (copyrights) dengan hak paten (yang tergabung dalam industrial property rights), sebanyak 18 orang (40,90\%).

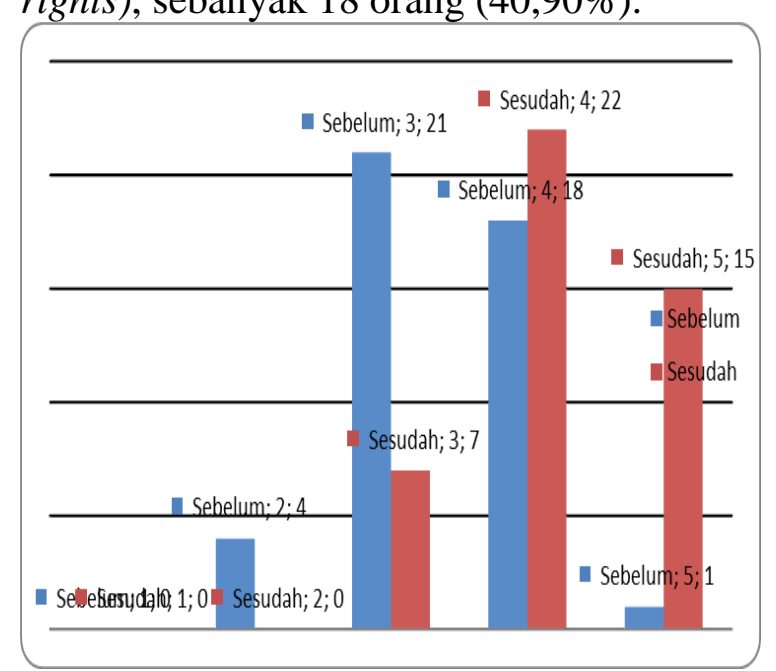


Diagram 2. Pemahaman perbedaan hak cipta dengan hak paten

\section{Pemahaman jenis-jenis Kekayaan intelektual lainnya (Merek, Desain, PVT, Rahasia Dagang)}

Sebelum pelatihan, jumlah guru yang belum memahami memahami jenis-jenis Kekayaan intelektual lainnya (Merek, Desain, PVT, Rahasia Dagang) dalam arti hanya mendapatkan skor di bawah atau sama dengan 3 sebanyak 28 orang, akan tetapi setelah pelatihan, jumlah guru yang mendapatkan skor di bawah atau sama dengan 3 hanya 9 orang. Sehingga ada kenaikan kemampuan guru dalam memahami jenis-jenis Kekayaan intelektual lainnya (Merek, Desain, PVT, Rahasia Dagang), sebanyak 19 orang $(43,18 \%)$.

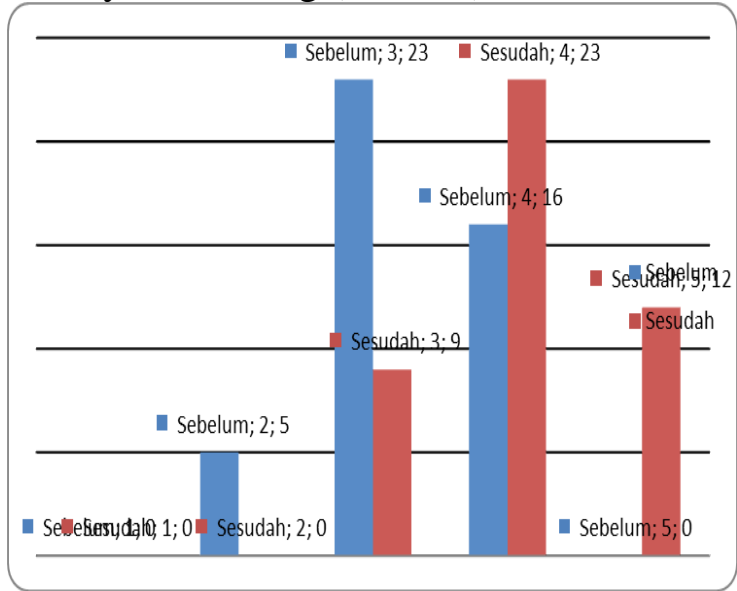

Diagram 3. Pemahaman jenis-jenis Kekayaan intelektual

\section{Pemahaman tentang plagiarism dan peraturan perundangan yang berlaku}

Sebelum pelatihan, jumlah guru yang belum memahami plagiarism dan peraturan perundangan yang berlaku dalam arti hanya mendapatkan skor di bawah atau sama dengan 3 sebanyak 23 orang, akan tetapi setelah pelatihan, jumlah guru yang mendapatkan skor di bawah atau sama dengan 3 hanya 10 orang. Sehingga ada kenaikan kemampuan guru dalam memahami plagiarism dan peraturan perundangan yang berlaku sebanyak 19 orang $(43,18 \%)$.

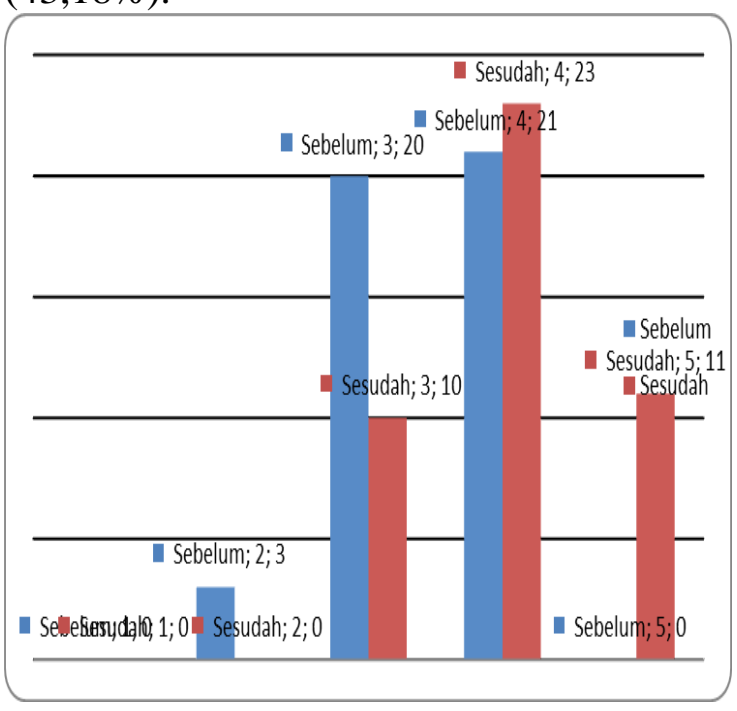

Diagram 4. Pemahaman tentang plagiarism dan peraturan perundangan yang berlaku

\section{Pemahaman siapa yang disebut pencipta dan apa hak cipta, Inventor dan invensi}

Sebelum pelatihan, jumlah guru yang belum memahami siapa yang disebut pencipta dan apa hak cipta dalam arti hanya mendapatkan skor di bawah atau sama dengan 3 sebanyak 20 orang, akan tetapi setelah pelatihan, jumlah guru yang mendapatkan skor di bawah atau sama dengan 3 hanya 9 orang. Sehingga ada kenaikan kemampuan guru dalam memahami siapa yang disebut pencipta dan apa hak cipta sebanyak 11 orang (25\%). 


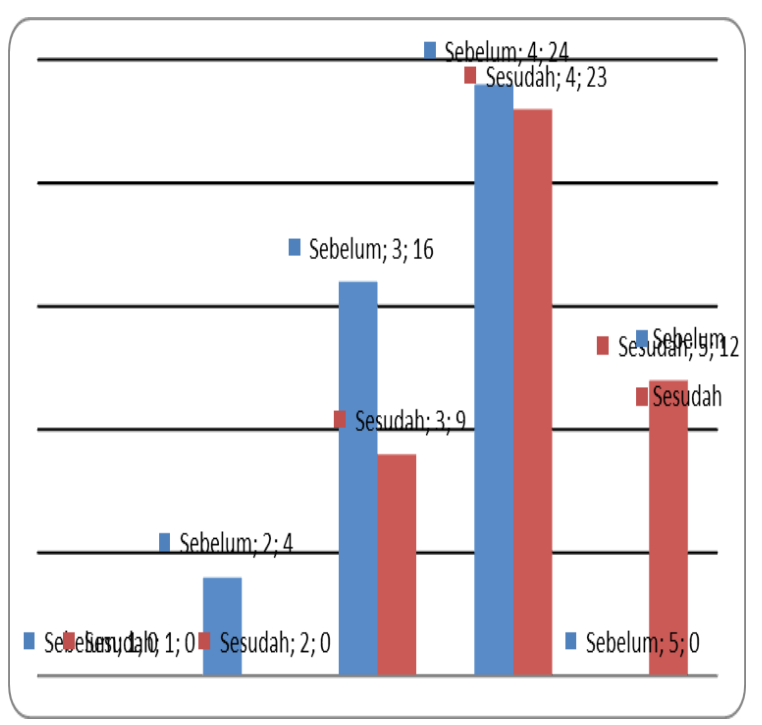

Diagram 5. Pemahaman siapa yang disebut pencipta dan apa hak cipta, Inventor dan invensi

\section{Pemahaman karakteristik perolehan hak cipta yang automatic protection}

Sebelum pelatihan, jumlah guru yang belum memahami karakteristik perolehan hak cipta yang automatic protection dalam arti hanya mendapatkan skor di bawah atau sama dengan 3 sebanyak 29 orang, akan tetapi setelah pelatihan, jumlah guru yang mendapatkan skor di bawah atau sama dengan 3 hanya 8 orang. Sehingga ada kenaikan kemampuan guru dalam memahami siapa yang disebut pencipta dan apa hak cipta sebanyak 21 orang $(47,72 \%)$.

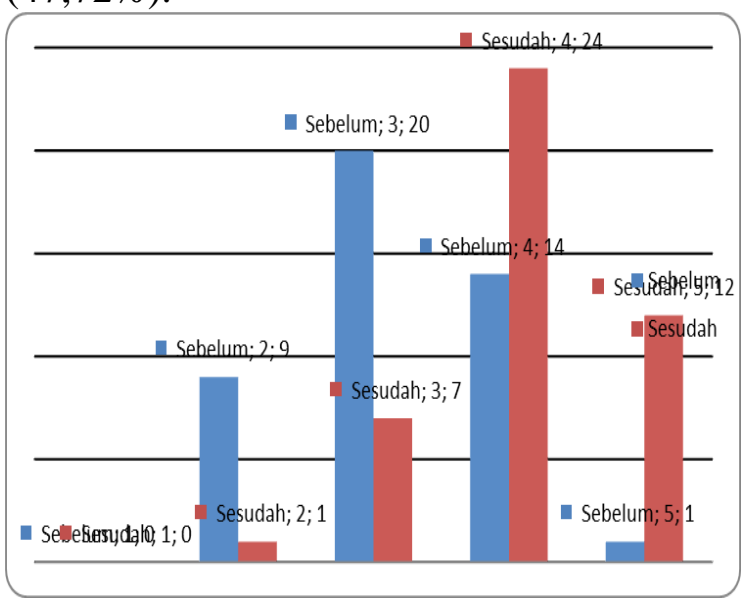

Diagram 6. Pemahaman karakteristik perolehan hak cipta yang automatic protection

7. Pemahaman obyek dan lingkup hak cipta dan paten sesuai UU terbaru (UU no.28 tahun 2014) dan UU no.13 thn 2016 tentang Paten, dan Merek UU 20 tahun 2016

Sebelum pelatihan, jumlah guru yang belum memahami obyek dan lingkup hak cipta, dan paten sesuai UU terbaru (UU nomor 28 tahun 2014 tentang Hak Cipta) dan UU no.13 thn 2016 tentang Patenm Dan merek UU 20 tahun 2016 dalam arti hanya mendapatkan skor di bawah atau sama dengan 3 sebanyak 26 orang, akan tetapi setelah pelatihan, jumlah guru yang mendapatkan skor di bawah atau sama dengan 3 hanya 14 orang. Sehingga ada kenaikan kemampuan guru dalam memahami obyek dan lingkup hak cipta dan paten sesuai UU terbaru (UU no.28 tahun 2014) dan UU no.13 thn 2016 tentang Paten? Dan merek UU 20 tahun 2016 sebanyak 12 orang $(27,27 \%)$.

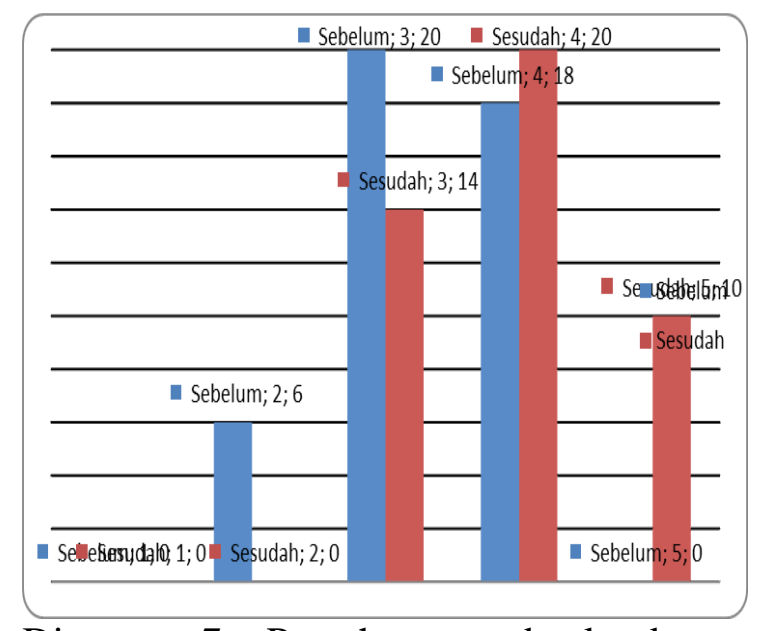

Diagram 7. Pemahaman obyek dan lingkup hak cipta 


\section{Pemahaman penyelesaiaan sengketa dalam HKI, pengalihan HKI, lisensi dan royalty.}

Sebelum pelatihan, jumlah guru yang belum memahami penyelesaiaan sengketa dalam HKI, pengalihan HKI, lisensi dan royalty dalam arti hanya mendapatkan skor di bawah atau sama dengan 3 sebanyak 22 orang, akan tetapi setelah pelatihan, jumlah guru yang mendapatkan skor di bawah atau sama dengan 3 hanya 8 orang. Sehingga ada kenaikan kemampuan guru dalam memahami penyelesaiaan sengketa dalam HKI, pengalihan HKI, lisensi dan royalty sebanyak 14 orang $(31,81 \%)$.

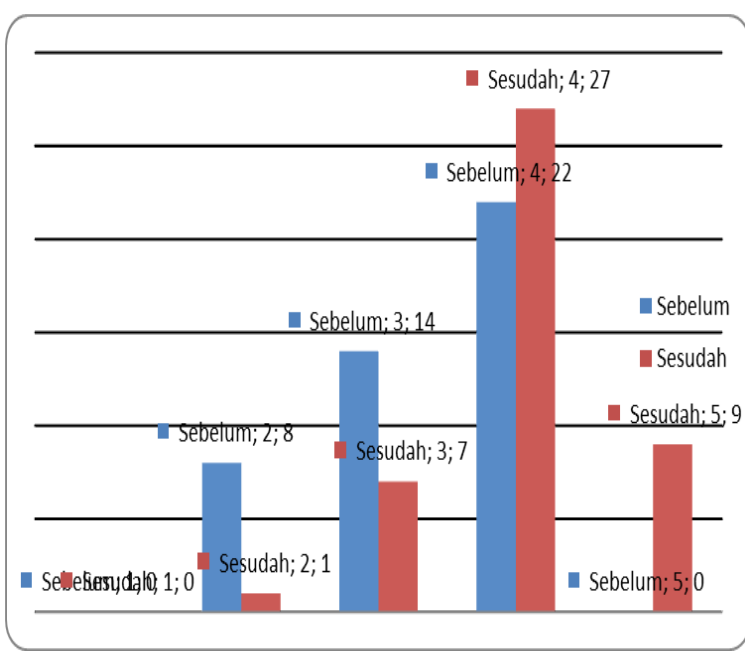

Diagram 7. Pemahaman penyelesaiaan sengketa dalam HKI, pengalihan HKI, lisensi dan royalty

\section{Pemahaman bahwa memfotokopi buku hanya sekedar untuk kepentingan pribadi (tidak diperjualbelikan) dan pendidikan itu dibolehkan}

Sebelum pelatihan, jumlah guru yang belum memahami bahwa memfotokopi buku hanya sekedar untuk kepentingan pribadi (tidak diperjualbelikan) dan pendidikan itu dibolehkan dalam arti hanya mendapatkan skor di bawah atau sama dengan 3 sebanyak 24 orang, akan tetapi setelah pelatihan, jumlah guru yang mendapatkan skor di bawah atau sama dengan 3 hanya 9 orang. Sehingga ada kenaikan kemampuan guru dalam memahami bahwa memfotokopi buku hanya sekedar untuk kepentingan pribadi (tidak diperjualbelikan) dan pendidikan itu dibolehkan sebanyak 15 orang $(34,09 \%)$.

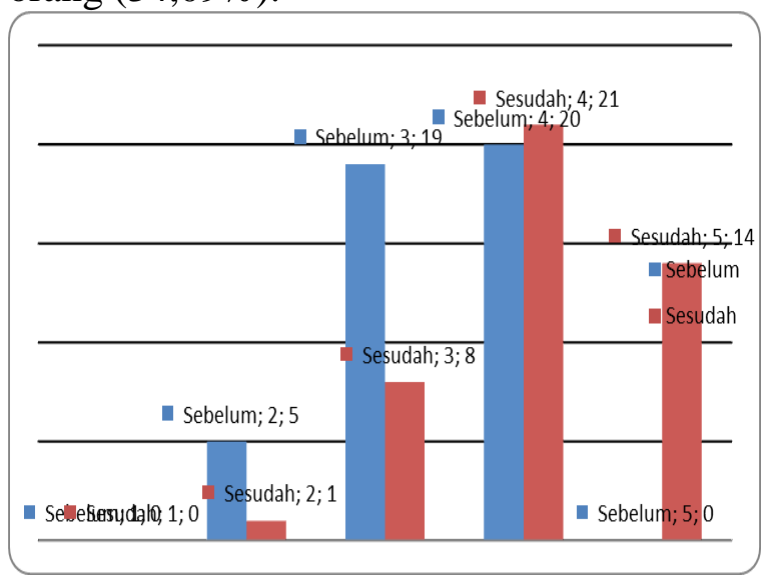

Diagram 9. Pemahaman bahwa memfotokopi buku hanya sekedar untuk kepentingan pribadi

\section{Pemahaman untuk kepentingan pencipta, maka ciptaan harus dicatatkan/dipublikasi.}

Sebelum pelatihan, jumlah guru yang belum memahami bahwa ciptaan harus dicatatkan/dipublikasi dalam arti hanya mendapatkan skor di bawah atau sama dengan 3 sebanyak 23 orang, akan tetapi setelah pelatihan, jumlah guru yang mendapatkan skor di bawah atau sama dengan 3 hanya 3 orang. Sehingga ada kenaikan kemampuan guru dalam memahami bahwa ciptaan harus dicatatkan/dipublikasi sebanyak 20 orang $(45,45 \%)$. 


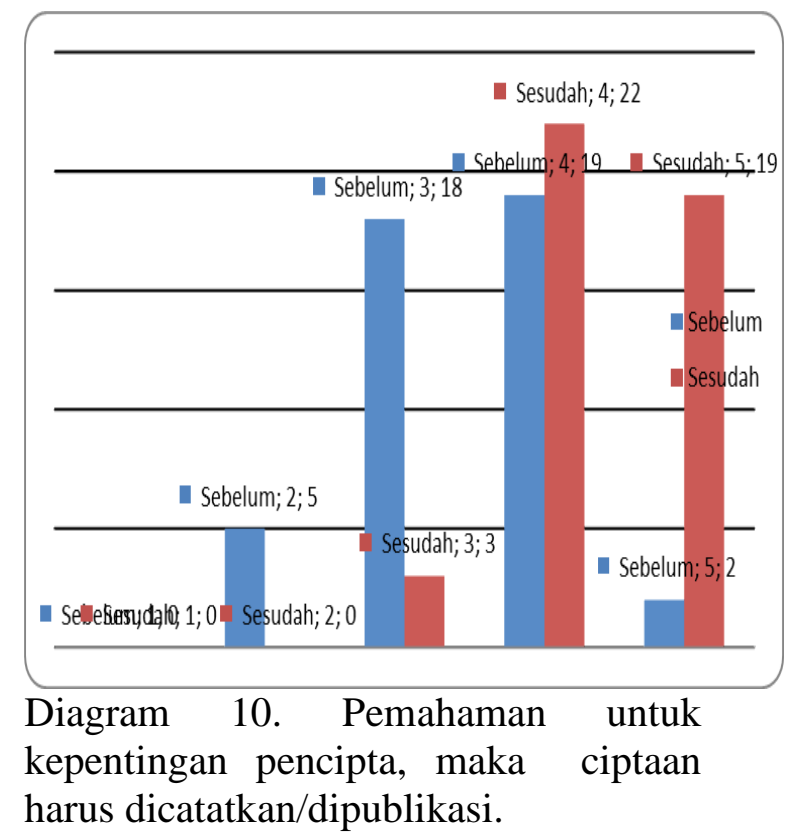

\section{Pemahaman perbedaan makna hukum: dicatatkan, didaftarkan dan dipublikasi}

Sebelum pelatihan, jumlah guru yang belum memahami perbedaan makna hukum: dicatatkan, didaftarkan dan dipublikasi dalam arti hanya mendapatkan skor di bawah atau sama dengan 3 sebanyak 19 orang, akan tetapi setelah pelatihan, jumlah guru yang mendapatkan skor di bawah atau sama dengan 3 hanya 6 orang. Sehingga ada kenaikan kemampuan guru dalam memahami perbedaan makna hukum: dicatatkan, didaftarkan dan dipublikasi sebanyak 13 orang $(29,5 \%)$. makna hukum: dicatatkan, didaftarkan dan dipublikasi

\section{Pemahaman delik yang berlaku dalam HKI}

Sebelum pelatihan, jumlah guru yang belum memahami delik yang berlaku dalam HKI dalam arti hanya mendapatkan skor di bawah atau sama dengan 3 sebanyak 23 orang, akan tetapi setelah pelatihan, jumlah guru yang mendapatkan skor di bawah atau sama dengan 3 hanya 14 orang. Sehingga ada kenaikan kemampuan guru dalam memahami delik yang berlaku dalam HKI sebanyak 9 orang $(20,4 \%)$.

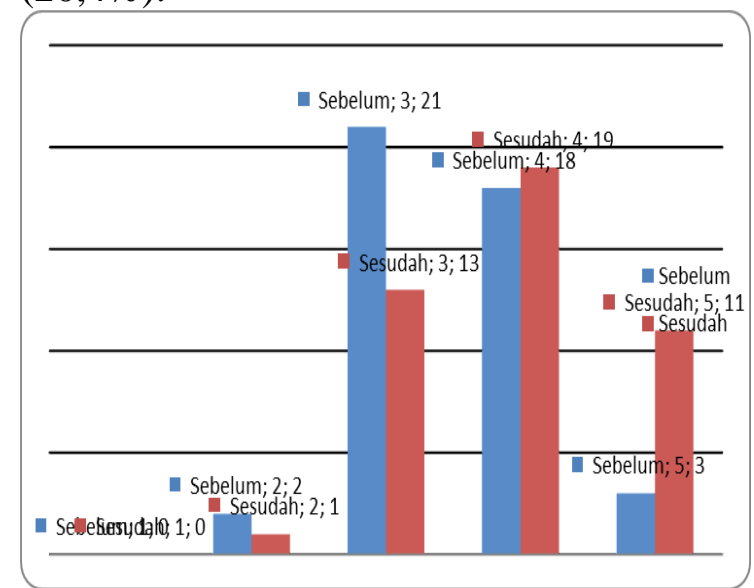

Diagram 12. Pemahaman delik yang berlaku dalam HKI 


\section{FOTO KEGIATAN}

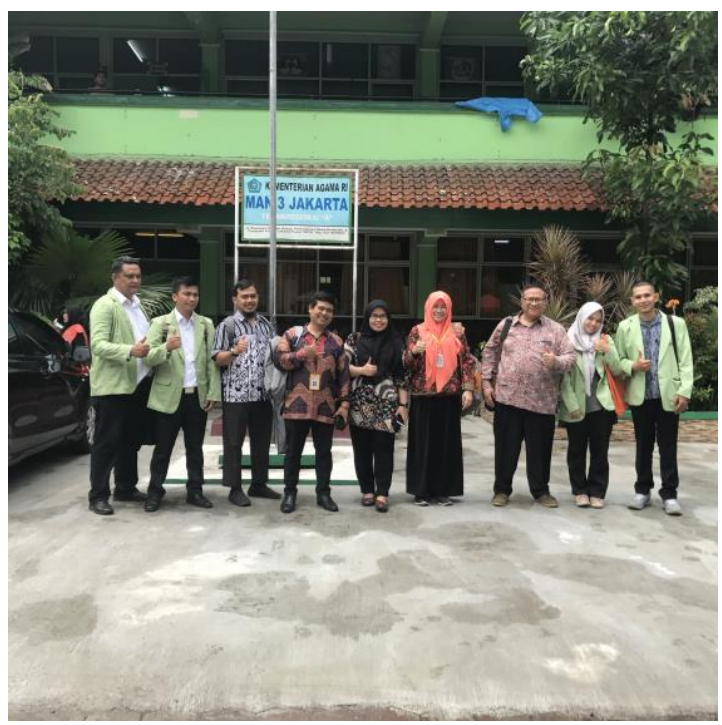

Suasana saat di halaman sekolah

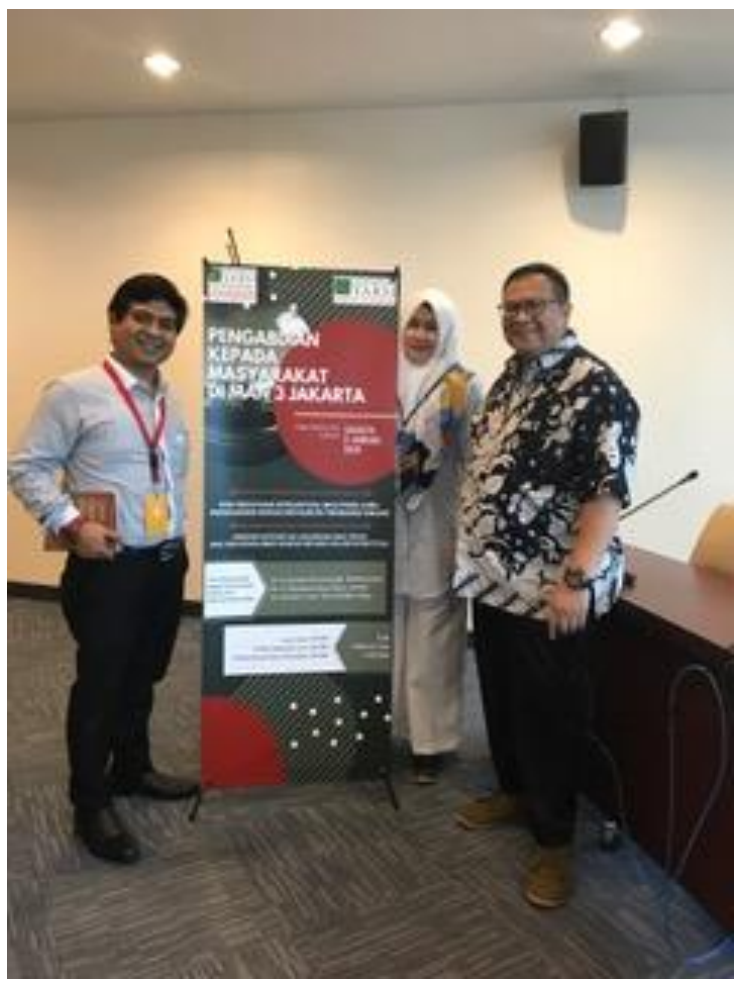

Bersama tim Pengabdi

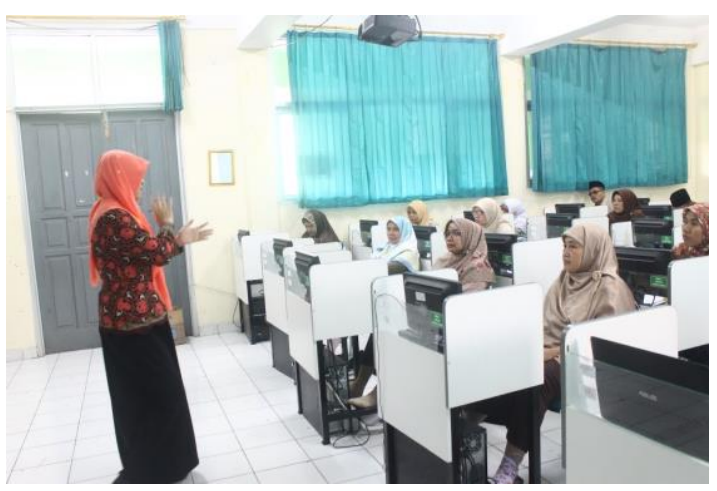

Ketua Tim sedang memberikan materi

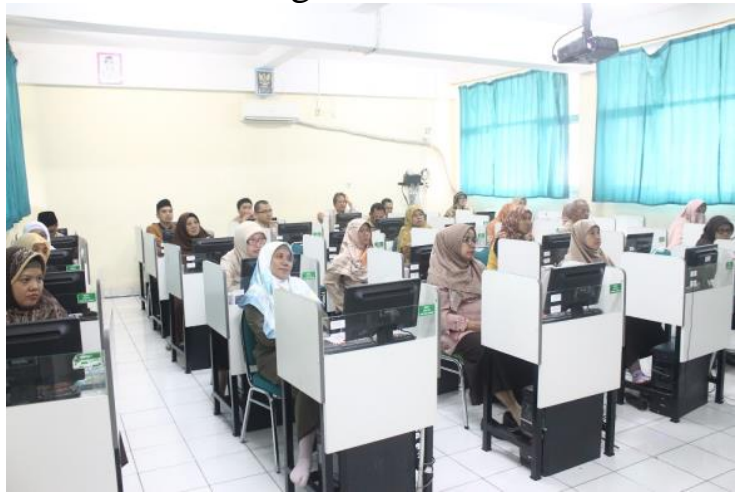

Suasana saat pelatihan

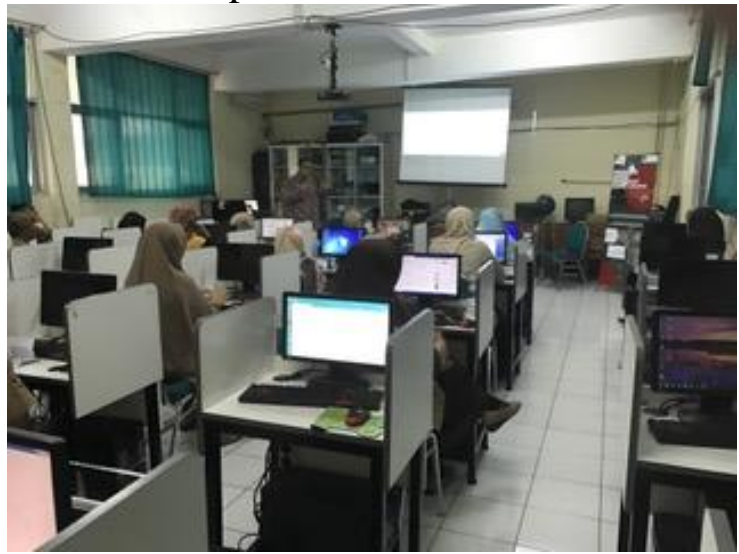

Suasana saat pelatihan

\section{KESIMPULAN}

Kegiatan telah dilaksanakan dengan baik, dan terjadi peningkatan pengetahuan guru MAN3 yang signifikan tentang HKI (20-60\%). Demikian juga:

1. Penyuluhan hukum HKI dapat meningkatkan pengetahuan HKI para guru agar makin sadar berkekayaan intelektual dengan dilakukan secara terprogram, sinergi antara Tim abdimas, 
Struktural MAN3 dan peserta (guru).

2. Faktor pendukung tumbuhnya kesadaran hukum guru terhadap HKI antara lain perkembangan era digital teknologi yang harus diadaptasi dengan baik oleh para guru dalam profesinya dan kebutuhan perlindungan kreativitas serta inovasi guru. Penghambat tumbuhnya kesadaran hukum guru terhadap HKI hanyalah merubah mindset yang membuat modul atau karya sekedar memenuhi kredit kum guru dan kewajiban bahan ajar mata pelajaran masing-masing guru.

\section{DAFTAR PUSTAKA}

BPHN, Seminar Hukum Nasional Keenam Buku I II, sebagaimana dikutip dalam Laporan
Pengabdian Kepada Masyarakat Pengusul 2015.

http://menzour.blogspot.com $/ 2016 / 03 / \mathrm{m}$ akalah-menganalis-uu-guru-dandosen.html diakses 13 Agustus 2018

Purwaningsih, Endang. 2012. HKI dan Lisensi, Bandung: Mandar maju

Tim Lindsley, dkk, 2011. Hak Kekayaan Intelektual suatu Pengantar, Bandung: PT Alumni

Undang-Undang nomor 14 tahun 2005 tentang Guru dan Dosen

Undang-Undang nomor 13 tahun 2016 tentang Paten

Undang-Undang nomor 20 tahun 2016 tentang Merek dan Indikasi Geografis

Undang-Undang nomor 28 tahun 2014 tentang Hak Cipta 